Gynecol.obstet Invest. 1982;14:I-IV

\title{
Contents, Vol. 14, 1982
}

\section{No. 1 Original Paper}

Gonadotropin Therapy of Female Infertility. Analysis of Results in 416 Cases

Zimmermann, R.; Soor, B.; Braendle, W.; Lehmann, F.; Weise, H.C.; Bettendorf, G. . 1 Ovarian Morphologic Features and Endocrine Profile in Amenorrheic Patients

Nakano, R.; Washio, M.; Hashiba, N.; Tojo, S

The Clinical Significance of Rheometric Measurement of Cervical Mucus Properties

Borenstein, R.; Apelman, Z.; Lancet, M.; Ben-Hur, H.; Hegesh, E 32

Dynamics of the Ampullary-Isthmic Junction in Rabbit Oviduct

Anand, S.; Guha, S.K 39

Endometrial Ossification: Unilateral Manifestation in a Septate Uterus

Wetzels, L.C.G.; Essed, G.G.M.; Haan, J. de; Kar, A.J.F. van de; Willebrand, D. . . 47 Effects of Selective Beta-Adrenergic Agonists on Spontaneous Contractions, cAMP Levels and Phosphodiesterase Activity in Myometrial Strips from Pregnant Women Treated with Terbutaline

Berg, G.; Andersson, R.G.G.; Rydén, G 56

Correlation between Hormonal Levels and Ultrasound in Patients with Threatened Abortion

Dessaive, R.; Hertogh, R. de; Thomas, K 65

Book Reviews

79

No. 2 Review

Ultrasonographic Placental Morphology

Hoogland, H.J 81

Original Paper

Demonstration of Human Papilloma Virus Antigen in the Condylomatous Lesions of the

Uterine Cervix by Immunoperoxidase Technique (with 1 color plate)

Syrjänen, K.J.; Pyrhönen, S 90

Ovarian Function during Treatment with High Ratio Levonorgestrel/Ethinyl Estradiol as Oral Contraceptives

Johansson, E.D.B.; Elamsson, K.; Elmestedt, U 97

Impaired Pregnenolone Secretion after Combined Cyproterone Acetate and Ethynyl Estra diol Therapy in Hirsute Patients

Inaudi, P.; D’Ambrogio, G.; Massafra, C; Facchini, V.; Genazzani, A.R 106

Comparison of Cornual Transfer via Laparotomy with Utero-Cervical Transfer of Culture Preimplantation Rat Embryos

Carp, H.J.A.; Shalgi, R.; Mashiach, S.; Serr, D.M.; Nebel, L

Pregnancy in Women with Congenital Antithrombin III Deficiency: Experience of Treat ment with Heparin and Antithrombin

Hellgren, M.; Tengborn, L.; Abildgaard, U 127

Contents $\prod \mathrm{I}$

Evaluation of the Total Lung Profile, Including the Two-Dimensional L/S Ratio for the 
Establishment of Fetal Lung Maturation

Feijen, H.W.H.; Di Renzo, G.C.; Nederstigt, J.; Houx, P.C.W.; Eskes, T.K.A.B 142

Characterization of Ritodrine Radioimmunoassay. Standard Curves, Cross-Reactions, and

Serum Levels in Women

Thomas, K.; Vankrieken, L.; Van Lierde, M 151

Book Reviews 156

No. 3 Original Paper

Morphological Characteristics of Different Types of Cystic Teratoma of the Ovary. A Study

of Surface Ultrastructure in Relation to Tumor Classification and Development

Stenbäck, F 161

Cyclic Changes in Cervical Microflora and Their Effect on Infections following Hysterec tomy

Thadepalli, H.; Savage, E.W., Jr.; Salem, F.A.; Roy, I.; Davidson, E.C., Jr 176

In vivo Endocrine Studies and Morphological Features in a Case of Hilus Cell Tumor in

Mesovarium Paradisi, R.; Venturoli, S.; Martinelli, G.; Serra, L.; Govoni, E.; Fabbri, R.;

Flamigni, C. . 184

Ultrastructure of Rabbit Endosalpinx and Glycoprotein Pattern of the Oviduct Fluid in the

Presence of Copper Intrauterine Devices David, A.; Levinsky, H.; Malik, Z.; Langzam, Y.;

Feller, N.; Shaked, P.; Allalouf, D. . 195

Identification and Characterization of Receptors for Oxytocin in the Myometrium of the

Pregnant Ewe

Crankshaw, D.J.; Romaniuk, E.; Branda, L.A

Biochemical Studies on Acid Phosphatase in Human Placenta and Fetal Liver during Devel opment

Kushari, J.; Chaudhury, I.; Chaudhury, D.; Mukherjea, M 214

Relative Fatty Acid Composition of Serum Lecithin in the Second Half of the Normal

Pregnancy

Rosing, U.; Johnson, P.; Ölund, A.; Samsioe, G 225

Current Investigation

Plasma Adrenocorticotropic Hormone, Beta-Lipotropin, and Beta-Endorphin in the Human

Fetus at Delivery. Correlation with Birth Weight and Placental Weight

Furuhashi, N.; Takahashi, T.; Fukaya, T.; Kono, H.; Shinkawa, O.; Tachibana, Y.;

Suzuki, M 236

Book Reviews 241

No. 4 Original Paper

Hormone Levels in Amniotic Fluid and Fetal Sex

Bremme, K.; Eneroth, P.; Nilsson, B 245

The Junctional Pattern of the Human Villous Trophoblast. A Freeze-Fracture Study

Virgiliis, G. de; Sideri, M.; Fumagalli, G.; Remotti, G 263

Fenoterol-Induced Changes of Urine Excretion, Body Weight, Blood Hematocrit, Hemoglobin,

Total Protein Values and Serum Electrolyte Levels in Pregnant Rabbits Fenske, M.;

Grospietsche, G.; Dietrich, B.; Ensink, F.B.M.; Hölzl, M.; Kuhn, W. . . 273

IV

Contents

Human Sperm Penetration into Cervical Mucus in vitro: Correlation between Its Quality, Penetration Capacity and Velocity 
Amit, A.; Bergman, A.; Yedwab, G.; David, M.P.; Homonnai, T.Z.; Paz, G

Mechanically Induced Tube Damage in the Artificial Hydrosalpinx

Kleinstein, J.; Neubiiser, D.; Mussmann, J 292

Lack of Association of Cytomegalovirus Antibody Level with Carcinoma of the Uterine

Cervix

Hart, H.; Springbett, A.; Norval, M 300

Book Reviews $\quad 309$

Author Index 315

Subject Index 317

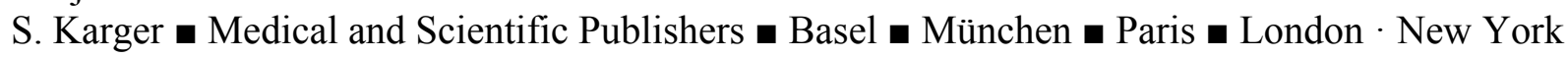

- Tokyo $\cdot$ Sydney

Drug Dosage

The authors and the publisher have exerted every effort to ensure that drug selection and dosage set forth in this text are in accord with current recommendations and practice at the time of publication. However, in view of ongoing research, changes in government regulations, and the constant flow of information relating to drug therapy and drug reactions, the reader is urged to check the package insert for each drug for any change in indications and dosage and for added warnings and precautions. This is particularly important when the recommended agent is a new and/or infrequently employed drug.

All rights reserved.

No part of this publication may be translated into other languages, reproduced or utilized in any form or by any means, electronic or mechanical, including photocopying, recording, microcopying, or by any information storage and retrieval system, without permission in writing from the publisher.

S. Karger AG, P.O. Box, CH-4009 Basel (Switzerland) Printed in Switzerland by Thür AG Offsetdruck, Pratteln 